\title{
1 Contemporary kinematics of the Ordos block, North 2 China and its adjacent rift systems constrained by dense GPS observations
}

${ }_{4}$ Bin Zhao $^{a, b}$, Caihong Zhang ${ }^{b}$, Dongzhen Wang ${ }^{b}$, Yong Huang ${ }^{b}$, Kai $\operatorname{Tan}^{b}$, Ruilin

The detailed kinematic pattern of the Ordos block, North China and its surrounding rift systems remains uncertain, mainly due to the low signal-to-noise ratio of the Global Positioning System (GPS) velocity data and the lack of GPS stations in this region. In this study, we have obtained a new and dense velocity field by processing GPS data primarily collected from the Crustal Motion Observation Network of China and from other GPS networks between 1998 and 2014. The GPS velocities within the Ordos block can be interpreted as counterclockwise rotation of the block about the Euler pole with respect to the Eurasia plate. Velocity profiles across the graben-bounding faults show relatively rapid rightlateral strike-slip motion along the Yinchuan graben, with a rate of $0.8 \sim 2.6 \mathrm{~mm} / \mathrm{a}$ 
from north to south. In addition, a right-lateral slip rate of $1.1 \sim 1.6 \mathrm{~mm} / \mathrm{a}$ is estimated along the central segment of the Shanxi rift. However, strike-slip motion is not detected along the northern and southern margins of the Ordos block. Conversely, significant extension motion is detected across the northwestern corner of the block, with a value of $1.6 \mathrm{~mm} / \mathrm{a}$, and along the northern segment of the Shanxi rift, where an extensional rate of $1.3 \sim 1.7 \mathrm{~mm} / \mathrm{a}$ is measured. Both the Daihai and Datong basins are experiencing crustal extension. On the southwestern margin of the block, deformation across the compressional zone of the Liupanshan range is subtle; however, the far-field shorting rate is as high as $3.0 \mathrm{~mm} / \mathrm{a}$, implying that this region is experiencing ongoing compression. The results reveal that presentday fault slip occurs mainly along the block bounding faults, with the exception of faults along the northern and southern margins of the block. These results provide new insights into the nature of tectonic deformation around the Ordos block, and are useful for assessing the seismic activity in this region.

Keywords: crustal deformation; Ordos block; fault slip rate; rift systems; block

\section{rotation}

\section{Introduction}

The Ordos block, which is the western part of the north China block (NCB),

is characterized by low strain rate and seismicity. In contrast, the margins of this 
stable block have been active since Cenozoic. The block is surrounded by four rift systems: the Yinchuan rift along its western margin, the Hetao rift along its northern margin, the Shanxi rift along its eastern margin, and the Weihe rift along its southern margin (Yin, 2010) (Figure $\mathbb{D})$. The block is surrounded by transtensional right-lateral shear faults to the east and west, and is bounded by left-lateral shear extensional faults to the north and south. The southwestern marginal belt of the block contains a thrust-fold zone in the Liupanshan area, which links with the northeast Tibetan Plateau. Over the past three decades, different models have been developed to describe the tectonic evolution of the graben systems around the Ordos block (Molnar and Tapponnier, 1975; Tapponnier and Molnar, 1977; Tian et al,, 1992; Northrup et al., 1995; Yin, 2010; Liu et al., 2007). Some researchers considered that the tectonic deformation and evolution of the Ordos area are the result of the far-field Indo-Asian collision (Molnar and Tapponnier, 1975; Tapponnier and Molnar, 1977). Alternatively, Some interpreted the idea that North China crustal thinning and volcanic activity may be closely related to the westward subduction of the Pacific plate beneath the Eurasian continent and the roll-back mechanism (Tian et al., 1992; Northrup et al., 1995)). Recently, effects from both Indo-Asian collision and Pacific-Asia subduction models have been combined to understand the extensional structures in north China (Yin, 2010; Liu et al,, 2007). 
Thus precise measurement of crustal deformation patterns in this region will be helpful to further improve these models.

In the last two decades, space geodetic techniques, especially the Global Positioning System (GPS) have been widely used for quantitative measurements of crustal deformation across tectonic deformation zones in mainland China (Chen et al., 2000; Shen et al., 2000, 2001; Wang et al., 2001; Zhang et al., 2004; Shen et al., 2005; Calais et al., 2006; Gan et al., 2007; Thatcher, 2007; Meade, 2007; Wang et al., 2011a). Kinematic studies in north China and the surrounding area show a first-order crustal deformation pattern in this region as follows. The north China region is moving at $\sim 5-11 \mathrm{~mm} / \mathrm{a}$ eastward relative to the stable Eurasia plate (Shen et al, 2000); Wang et al., 2001). The GPS-based study of Shen et al. (20)(0) showed that the northern segment of the Shanxi rift around $40^{\circ} \mathrm{N}$ is under ESE-WNW extension at a rate of $4 \pm 2 \mathrm{~mm} / \mathrm{a}$. He et al. (20)(3) compiled more GPS data sets but did not detect clear signs of extension across the same segment of the Shanxi rift. In the study of He et al. (2003), the discrepancy was ascribed to time-dependent crustal deformation. Recently, Wang et al. (2011a) reported the fault slip rates of major faults around the Ordos block using an elastic block model based on GPS data from 1999 to 2007, which depicted the first-order kinematic features. However, more detailed knowledge of graben-bounding fault slip 
rates for determining the relative activity along the different segments of the same fault or different faults qualitatively are yet to be archived. These parameters are important not only for understanding the deformation mechanism of North China but also for assessing the earthquake hazards in the rift systems surrounding the block (Meade and Hager, 2005).

In this study, following a brief introduction of the GPS data processing, we present the latest horizontal velocity field around the Ordos region based on more recent GPS data. We then present the method of estimating the slip rates of graben-bounding faults around the stable block in the framework of the rigidly rotating Ordos block itself and document the detailed kinematic characteristics of these faults. Finally, we compare the results with previous geodetic and geologic results and discuss the implications of the findings for the crustal deformation.

\section{GPS data and processing}

6 GPS data used in this study are mainly obtained from the Crustal Movement Observation Network of China(CMONOC) project from 1999 to 2014 (Ma et al,, 2001); Wang et al., 20033; Niu et al., 2005; Li et al,, 2012). There are 61 continuous GPS stations and 615 survey mode stations in the study area. All the survey mode stations were observed continuously for at least 4 days during each session. In 
addition, we also collected GPS data from 2000 to 2014 at 224 campaign stations. Some of them have been established to monitor regional crustal deformation and others are used as survey control markers.

All the GPS Receiver-Independent Exchange(RINEX) data were processed using GAMIT/GLOBK software (Herring et al., 2010) in three steps (Zhao et al, 2015). First, the GPS carrier phase data were processed to obtain loosely constrained daily solutions for satellite orbits, station positions, satellite antenna offsets, and atmospheric zenith delay parameters. Second, the regional daily solutions were combined with the global solutions produced by the Scripps Orbital and Position Analysis Center (SOPAC, http://sopac.ucsd.edu/) using the GLOBK software (Herring et al., 2010), and then aligned into to ITRF2008 (Altamimi et al., 2011) through approximately 50 globally distributed reference stations using seven parameters transformation: translation, rotation, and scale. Third, velocities were estimated along with offsets induced by earthquakes or equipment changes from position time series using the least squares method. In the solution (for which spans were longer than 2.5 years), we determined the random walk to be applied using the "realistic sigma" method of Herring (2003) and described by Reilinger et al. (2006). The velocity field was finally transformed into the Eurasiafixed reference frame using plate rotation poles from Altamimi et al. (2011). 
The GPS horizontal velocity data contain some outliers from various nontectonic sources. These outliers are usually of large formal errors and are not coherent with other nearby observations, and mainly due to poor observational conditions (sky visibility and multipath issues), or instability of the monuments from sources such as ground water withdrawal, and too short observation spans. Thus, velocity values are rejected if they satisfy any of the following criteria: (1) GPS stations with too short observational time span, typically shorter than 2.5 years, which is the minimum time span for estimating reliable velocity according to Blewitt and Lavalle (20(2)). (2) Velocity values that are visually different from nearby velocities. These outliers are recognized by detecting large residuals between the interpolated values using the Kriging method and observations. (3) Vectors with uncertainties larger than three times the average uncertainty. After excluding outliers, we finally obtain regional horizontal velocity values at 724 stations (Figure Q, see the supplementary for GPS velocity). The average velocity uncertainties are 0.26 and $0.28 \mathrm{~mm} / \mathrm{a}$ for the east and north components respectively. The vertical motion in this region are poorly determined, and stations located in the graben systems are contaminated heavily by rapid subsidence caused by groundwater withdrawal. We therefore do not examine the vertical motion in this study. 


\section{Estimation of the fault slip rates}

\subsection{Ordos reference frame}

A major issue in interpreting GPS-derived surface velocities is to choose the appropriate reference frame. For the kinematic analysis, the velocity field is transformed from the Eurasian reference frame into the Ordos reference frame. In this section, we compute the position and angular velocity of the Euler pole of the Ordos block for the Eurasian reference frame. As the Ordos is one of the most stable blocks in mainland China from geological view (Replumaz, 2003) and there is a very low strain rate within the block from the geodetic perspective, GPS vectors within the block are used as much as possible to estimate the Euler vector via an iterative procedure. During each iteration, the site with the largest postfit residual is rejected and the estimation is redone, until the postfit residual velocities fit a normal distribution with a mean value close to zero. We finally use 62 GPS stations to define the Euler vector. The residual velocities are between -1.5 and $1.5 \mathrm{~mm} / \mathrm{a}$, with a mean value of $0.18 \mathrm{~mm} / \mathrm{a}$ and a variance of $0.68 \mathrm{~mm} / \mathrm{a}$. The final best fit model is illustrated in Figure [3. The angular velocity pole of rotation from Eurasia to Ordos is located at $116.48^{\circ} \mathrm{E}, 51.81^{\circ} \mathrm{N}$ with a counterclockwise rotation rate of $0.168 \mathrm{rad} / \mathrm{Ma}$. These results show good agreement with previously published GPS-based models of the Ordos block motion (Wang et al., 2011a). In 
contrast, it differs from the geological results (Replumaz, 20(3) $)$, which were defined graphically from the trends of Quaternary active normal faults bounding the grabens and from the mean tensional stress axes computed from focal solutions of earthquakes and kinematics of late Cenozoic faults in this region (Zhang et al., 1998). This discrepancy is probably result from the difference in timescales of the geological and geodetic models.

The GPS horizontal velocity field with respect to the stable Ordos block in Figure 1 further confirms that deformation is very subtle in the interior of the block and only occurs along the rift systems around the Ordos block, particularly concentrates on the southwestern margin.

\subsection{Velocity profiles and average velocity method}

In order to investigate the kinematic characteristics of the rift systems around the block in detail, twelve velocity profiles are studied across chosen rifts or faults. These profiles are based on the Ordos fixed local reference frame, such that there are no rotational effect left on the Ordos block side of the velocity field. The profiles illustrated in Figure 4 are mainly across the faults close to the block, and the length and width of each profile are determined depending on the fault we investigated. For example, profile length and width are shorter for the Luoshan fault (profile L in Figure 4 ) than others, avoiding slip rate basis from the Haiyuan 
fault.

Because of the low fault slip rates, we do not employ dislocation for strike-slip fault or reverse-slip faults to constrain the slip rate and lock depth simultaneously. We only estimate the slip rates of individual faults by calculating the differences in the average site velocities on both sides of the fault trace. In general, the velocity profiles run across the basins around the Ordos block, basin-bounding faults, and other faults. To delineate the detailed kinematic features, the slip rates are estimated if it appeared obvious difference motion across the fault. The uncertainties of those slip rates are the sum of the dispersions between the site velocities, with the dispersion being calculated as the root-mean-square of the differences of individual site velocities with respect to the mean velocity (Walpersdorf et al., 2014).

\section{Results}

The slip rates for major faults around the Ordos block are summarized in Table [, and illustrated in Figures [ 5 and 6 . In the following subsections, detailed fault slip results are documented.

\subsection{Yinchuan graben}

The Yinchuan graben is controlled by the range-front fault of the Helan Mountains to the west and the Huanghe Fault to the east (Deng and Liao, 1996). The 
thickness of Quaternary sediments within the basin is as much as $2000 \mathrm{~m}$. During historic times, one earthquake with magnitude of 8 occurred in the Yinchuan Basin. The magnitude 8 Yinchuan Pingluo earthquake on January 3, 1739 had a maximum intensity of more than 10 (Deng and Liao, 1996). The focal mechanism of this event indicates right-lateral strike slip motion. In this study, we determine the right-lateral slip across the Yinchuan rift at a rate of $2.1 \pm 1.0 \mathrm{~mm} / \mathrm{a}$. This value is slightly less than the $2.6 \mathrm{~mm} / \mathrm{a}$ right slip across the Yinchuan rift reported by Wang et al. (20/la). An extensional slip at a rate of $1.2 \pm 0.7 \mathrm{~mm} / \mathrm{a}$ is estimated, which agrees well with the results of Wang et al. (20)1a). It is still hard to determine the partitioning of slip between the Helan Fault and the Huanghe Fault, although there are several GPS stations in the Yinchuan Basin. From visual inspection, however, an extension rate of roughly $2.0 \mathrm{~mm} / \mathrm{a}$ is inferred across the Bayanwulashan, which is located approximately $100 \mathrm{~km}$ west of the Helan Mountains (Figure 4).

\subsection{Jilantai graben}

To the north of the Yinchuan graben, the nearly NS trending Jilantai graben is bounded by the Dengkou-Benjing buried fault to the east and by the Bayanwulashan to the west. The thickness of Quaternary sediments within this graben is as much as $400 \mathrm{~m}$. The result for the fault-parallel velocity component indicates 
that the right-lateral slip is only $0.8 \pm 0.7 \mathrm{~mm} / \mathrm{a}$ across the Bayanwulashan fault (Figure 5BB). The extensional slip rate across the Jilantai Basin, however, is relatively larger, $1.6 \pm 0.4 \mathrm{~mm} / \mathrm{a}$. A Ms 5.8 earthquake occurred in this basin on April 15,2015 , with a strike-slip focal mechanism solution, which is consistent with the tectonic background stress.

\subsection{Hetao graben}

The EW trending Hetao graben is located on the northwestern segment of the Ordos block. From a geographical perspective, this graben is the northern extension of the Yinchuan-Jilantai graben. It is controlled by the frontal LangshanSeertengshan fault to the north and by the north frontal Ordos fault to the south. The slip rates of both fault-parallel and fault-normal components are very low: left-lateral slip rate of $0.3 \pm 0.9 \mathrm{~mm} / \mathrm{a}$ and extension of $0.5 \pm 1.0 \mathrm{~mm} / \mathrm{a}$ (Figure $5 \mathrm{C}$ ). Our results are consistent with the left-lateral slip rate of $0.6 \mathrm{~mm} / \mathrm{a}$ and the extensional rate of $0.5 \mathrm{~mm} / \mathrm{a}$ inferred from a block model derived using GPS data by Wang et al. (201la). Although there are eight stations in the Hetao Basin, it is difficult to distinguish the partitioning of slip between the south and north edges of the basin due to their low signal-to-noise ratios. 


\subsection{Baotou-Hohhot graben}

The EW trending Baotou-Hohhot graben is the eastern extension of the Hetao graben: the entire system has been called the Hetao rift system in previous studies. The east end of the Baotou-Hohhot graben is the Shanxi rift; however, how the Hetao and Shanxi rifts terminate in the north is not clear (Yin, 2010). Figure SD shows the deformation across the Baotao-Hohhot graben. Left-lateral slip of only about $0.6 \pm 0.8 \mathrm{~mm} / \mathrm{a}$ is measured across the north frontal Ordos fault. In contrast, a slip rate of approximately $0.4 \sim 0.6 \mathrm{~mm} / \mathrm{a}$ is estimated across the Daqingshan fault, which is the northern edge of the basin and is a fold-and-thrust belt (Davis and Darby, 2010). However, this result may be arguable because the uncertainty in the estimated slip is large.

\subsection{Datong graben}

The Datong graben is located in the northern segment of the Shanxi rift. This segment contains a series of en echelon depressions bounded by normal faults, in which Quaternary basaltic volcanoes are present (Xu et al, 1993). A velocity profile is projected across the Liulengshan fault, which is the southeastern boundary of the Datong graben. The profile also runs across the Daihai normal fault and the Kouquan fault, which is the northwestern boundary of the basin. No obvious left-lateral slip across the graben is observed, but extensional deformation is de- 
termined to be dominant (Figure $5 \mathrm{E}$ and $\mathrm{F}$ ). The total extensional slip is $1.3 \pm 0.5$ $\mathrm{mm} / \mathrm{a}$ across the Daihai and Datong from northwest to southeast, in which the Kouquan fault accommodates $0.8 \mathrm{~mm} / \mathrm{a}$ extensional slip, absorbing more than $60 \%$ of the total extensional deformation.

On the southwestern segment of the Datong graben, the horizontal velocity is projected parallel to the strike of the north frontal Hengshan fault and along faultnormal components. The velocity profile illustrates subtle right-lateral slip but significant fault-parallel motion with an extensional slip rate up to $1.7 \pm 0.7 \mathrm{~mm} / \mathrm{a}$ across the whole profile. Extensional slip rates of approximately $1.1 \mathrm{~mm} / \mathrm{a}$ and 0.6 $\mathrm{mm} / \mathrm{a}$ are measured across the Daihai fault and the north frontal Hengshan fault respectively. Thus, GPS velocity profiles across the Datong Basin demonstrate that the extensional deformation is still occurring in this region. The value for extensional slip herein is less than that of the model documented by Shen et al. (20()) whose GPS campaign solutions were derived from 1996 to 2001.

\subsection{Xinding graben}

The Xinding graben is located in the north-central segment of the Shanxi rift, and contains the Daixian, Yuanping, and Dingxiang depressions. The graben is bounded by the Yunzhongshan frontal fault to the west, by the Wutaishan frontal fault to the northeast, and by the Xizhoushan frontal fault to the east. There are 
historical records of three magnitude 7 earthquakes in this basin. The Yunzhongshan frontal fault shows undetectable fault normal motion but a right-lateral slip of $1.7 \pm 0.5 \mathrm{~mm} / \mathrm{a}$ (Figure $5 \mathrm{G}$ ). Other mapped faults located in the east of the Yunzhongshan frontal fault, which are called the Wutaishan and Xizhoushan frontal faults, show no detectable strike-slip motion; therefore, the right-lateral strike-slip is confined to the Yunzhongshan frontal fault. The dextral component is much larger than the average slip rate for the entire Shanxi rift system given by Wang et al. (2011a).

\subsection{Taiyuan graben}

The Taiyuan graben is situated in the middle of the Shanxi rift, and is a major NE trending basin. The graben is enclosed by the Jiaocheng fault to the northwest and by the Taigu fault to the southeast, and extends for about $90 \mathrm{~km}$ along the Fen River from the Taiyuan city in the north to the Lingshi city in the south. We observe a right-lateral strike-slip of $1.1 \pm 0.9 \mathrm{~mm} / \mathrm{a}$ across the whole basin; however the slip partitioning across the Jiaocheng and Taigu faults is not clear due to the lack of enough GPS sites within the basin. The GPS-derived extension rate across the Taiyuan Basin is less than $0.3 \mathrm{~mm} / \mathrm{a}$. These results are close to those of Wang et al. (2009), who predicted right-lateral slip rate along whole Shanxi rift on the basis of an earlier GPS solution. 


\subsection{Linfen graben}

The Linfen graben is the southernmost segment of the Shanxi rift. It is bounded by the Luoyunshan frontal fault to the west (Zhang et al., 20(3) ) and by the HuoshanFushan frontal fault to the east ( $\mathrm{Xu}$ et al, 1993). Two magnitude 8 destructive events, the Hongdong earthquake of 1303 and the Linfen earthquake of 1605, occurred in the basin( $\mathrm{Xu}$ et al., 1993; Liu et al, 20(07). The Hongdong earthquake took place on the Huoshan fault in the south and ruptured the Taigu fault in the north with a total rupture length of approximately $163 \mathrm{~km}$ (Jiang et al., 20(04), while the Linfen earthquake was related to the abrupt sinistral offsetting of the WNW-trending fault in the Linfen graben ( $\mathrm{Xu}$ et al., 1993). The presence of abundant ground fissures and Quaternary faulting indicate that this region is still tectonically active. The GPS velocity profile across the Linfen Basin shows a dextral slip at a rate of $0.8 \pm 0.7 \mathrm{~mm} / \mathrm{a}$ and subtle extensional slip at a rate of $0.2 \pm 0.6$ $\mathrm{mm} / \mathrm{a}$. The fault-parallel velocity profile (Figure 6I) shows that the deformation difference across the Luoyunshan frontal fault is negligible, while the velocity difference across the Huoshan-Fushan frontal fault is significant.

\subsection{Weihe graben}

The nearly east trending Weihe graben is the southern margin of the rigid Ordos block. It is bounded to the south by the Qingling Mountains, which were 
formed by the collision of the North China and South China blocks during the Triassic Preiod, and to the north by the Beishan Mountains. At least three large historic earthquakes with magnitude greater than 7 have occurred in the Weihe graben, including the 1556 M8.5 Huaxian great earthquake that caused more than 830,000 deaths (?). The high level of historical seismicity indicates that the normal faults in the Weihe Basin are still currently active. Previous work showed that the Weihe rift has a sinistral slip at a rate of $1.4 \pm 0.4 \mathrm{~mm} / \mathrm{a}$ (Wang et al., 2011a); however, the GPS results of this study indicate no obvious deformation in both the fault-parallel and fault-normal components (Figure 6J).

\subsection{Liupanshan thrust system}

The Liupanshan thrust belt on the southwestern edge of the stable Ordos Plateau is the transitional zone between the Tibetan Plateau and the Ordos block. This thrust fault started its formation during the Pliocene. Zhang et al. (20(1)4) pointed out that shortening occurs in this area at a rate of $6.0 \pm 2.0 \mathrm{~mm} / \mathrm{a}$ along over zones of hundreds of kilometers in the direction $\mathrm{N} 75^{\circ} \mathrm{E}$. The fault-normal component of the GPS velocity profile across the Liupanshan thrust shows approximately continuous deformation across the southwestern side of the fault over a distance of $150 \mathrm{~km}$, but the estimated shortening rate is $3.0 \pm 1.1 \mathrm{~mm} / \mathrm{a}$, only half of that reported by Zhang et al. (20(1)). Lateral strike-slip was not determined for 
the Liupanshan fault in previous works. In this study right-lateral slip at a rate of $1.6 \pm 0.8 \mathrm{~mm} / \mathrm{a}$ over a distance of more than $200 \mathrm{~km}$ is calculated, and the deformation pattern suggests that the lateral strike-slip is not localized at the Liupanshan. This result is not consistent with the small left-lateral slip determined by Wang et al. (2011a) from an elastic block model. Furthermore, the difference in deformation within $50 \mathrm{~km}$ on both sides of the Liupanshan thrust fault appears to be negligible, which is similar to the subtle shortening across the Longmenshan fault before the Wenchuan earthquake (Shen et al, 2005).

\subsection{Luoshan fault}

The NS trending Luoshan fault connects the southern tip of the Yinchuan graben (Qingtongxia) and the northern end of the Liupanshan fault, and is the central segment of the western boundary of the Ordos block. Approximately 2.6 \pm 0.9 $\mathrm{mm} / \mathrm{a}$ of right-lateral slip and an undetectable extensional rate are constrained for this fault from the GPS velocity data. The lateral slip rate in this segment is the largest one around the Ordos block, and is consistent with the result of Wang et al. (2011a). 


\section{Discussion}

\subsection{Comparison between geodetic and geologic slip rates}

The neotectonic deformation of the graben-bounding faults around the Ordos block has been studied previously using available geological data, field investigations(Xu et al., 1993; Deng and Liao, 1996; Zhang et al., 2003; Min et al, 2003). Most previous studies have focused on the Yinchuan and Shanxi rifts, especially on the faults where historical earthquakes ruptured. For the Shanxi rift, the kinematic deformation is characterized by its S-shaped geometry with broad extensional domains in the north and south and a narrow transtensional zone in the middle (Zhang et al., 2003). Our new results are more close to the average fault slip rate of $1 \sim 4 \mathrm{~mm} / \mathrm{a}$ on the western border faults of the NNE-trending basins (Ma, 1987). However, right-lateral slip rates from Xu et al. (1993) are generally a factor of $3 \sim 8$ times greater than geodetic ones for the Shanxi rift. Previous geological work demonstrated that right-lateral slip of $4.9 \sim 6.4 \mathrm{~mm} / \mathrm{a}$ occurs at the Huoshan fault in the central-southern part of the Shanxi rift, decreasing to $5.68 \mathrm{~mm} / \mathrm{a}$ at the Xizhoushan fault, and finally reducing to less than $4 \mathrm{~mm} / \mathrm{a}$ in the north end of the rift during the Holocene according to the previous geological work (Xu et al, 1993). The geodetic fault slip data in this study, in contrast, indicate much smaller values of the right-lateral strike. The right-lateral slip rate 
of the entire Shanxi rift is no more than $2.0 \mathrm{~mm} / \mathrm{a}$, with maximum slip occurring across the Xinding graben, and $0.8 \mathrm{~mm} / \mathrm{a}$ right-lateral slip across the Linfen graben that is bounded by the Huoshan fault to the east. The slip rate discrepancy, especially at the Huoshan fault, may be attributable to their critical position in the rift system and also the magnitude 7 8 earthquakes that they have ruptured, and the maximum amount of surface displacement caused by those earthquakes (Xu et al,, 1993).

For the western margin of the Ordos block, Min et al, (2003) reported a minimum slip rate of $2.15 \pm 0.2 \mathrm{~mm} / \mathrm{a}$ on the Luoshan fault, which is located at the northeastern margin of the Tibetan Plateau. This fault strikes roughly N-S, based on the right-lateral strike-slip offsets of the oldest alluvial fan, and of a gully, and on the average displacement of the same order of gullies. Right-lateral strike-slip at a rate of $2.6 \mathrm{~mm} / \mathrm{a}$ is measured on the basis of the GPS data in this study, which agrees well with the geological result but is less than the crude value for the whole rift system. Different GPS-derived slip rates in the western segment of the block show good coincidence, however, different geological results may be biased by the differences in geological dating. For example, Min et al. (2003) estimated that the right-lateral slip at the Luoshan fault has been about $2.15 \mathrm{~mm} / \mathrm{a}$ since the Late Pleistocene, whereas Deng and Liao (1996) reported a rate of $4 \sim 5 \mathrm{~mm} / \mathrm{a}$ since 
the Holocene for the same fault. The discrepancy between the short-term geodetic and secular geological slip rates can probably be attributed to secular variation in slip history or systematic errors caused by different methodological approaches to reconstruction of offsets (Cowgill, 2007).

For the extensional component, the geodetic and geologic fault slip values show good agreement. Zhang et al. (1998) documented an extensional slip rate of $0.5 \mathrm{~mm} / \mathrm{a}$ across the central Shanxi graben, and an opening rate of $3.1 \mathrm{~mm} / \mathrm{a}$ on the northwestern margin of the Ordos block. GPS-based results also reveal that the extensional rate is insignificant in the central Shanxi rift and has a much more significant value of $1.6 \mathrm{~mm} / \mathrm{a}$ across the Jilantai graben. Both geodetic and geologic fault slip values demonstrate that extensional deformation is confined only to individual locations in the rift systems around the Ordos block rather than occurring in the all graben systems.

\subsection{Kinematic pattern of the southwestern Ordos block and its counterclockwise} rotation

The southwestern margin of the Ordos block connects with the northeast corner of the Tibetan Plateau, where thrust structure faults and folds are well developed. The GPS velocity profile across the Liupanshan thrust fault indeed shows a significant shortening over a distance of approximately $300 \mathrm{~km}$; however, no 
obvious velocity differences are observed close to the Liupanshan fault (Figure $6 \mathrm{~K})$, implying that the fault maybe locked and is building up elastic strain. Spirit leveling data across the northern segment of the Liupanshan demonstrats that a maximum uplift rate of more than $6 \mathrm{~mm} / \mathrm{a}$ is measured near the fault trace on the hanging wall, similar to the vertical deformation pattern prior to the $\mathrm{Mw} 7.9$ Wenchuan earthquake of 2008 (Hao et al, 2014). Thus, this area has been the focus of a great deal of attention. More detailed fault coupling ratio based on geodetic observation and historic earthquakes should be investigated in future.

Counterclockwise rotation of the Ordos block have been observed by geological field works and GPS measurements. So what is the possible mechanism of the block rotation? Zhang et al. (1998) proposed that the Ordos block rotates counterclockwise as a result of the push of Tibet through the left-lateral strikeslip Haiyuan fault and the Liupanshan thrust and fold belt. They also inferred that the left-lateral strike-slip Kunlun-Taibai faults have also rotated the continental fragments, such as the Ordos block (Zhang et al., 1998). This study provides further evidences from a geodetic perspective. Crustal shortening rate across the Liupanshan thrust fault results from stress transferred from northeastern Tibet, which is the most important mechanism for the block rotation. Additionally, rapid deformation occurs along the east left-lateral strike-slip Haiyuan fault, which ter- 
minates against the compressional zone of the Liupanshan range. Therefore, it is likely that the left-lateral slip on the Haiyuan fault may have been transferred to push the southwestern margin of the block, and may consequently have caused the block to rotate counterclockwise. However, it is uncertain whether the left-lateral Taibai-Qinling faults have played an important role, as there is no detectable fault slip along the Taibai-Qinling faults based on GPS measurements.

\subsection{Implications for opening of the northern Shanxi rift}

Interestingly, a striking deformational feature is detected in the northern segment of the Shanxi rift. The deformation is not the same as the significant opening across the Daihai basin of as much as $4 \pm 2 \mathrm{~mm} / \mathrm{a}$ reported by Shen et al. (2000), nor is it the smooth variation across the active faults presented by He et al. (20)3). On the basis of improved GPS station coverage and a longer time span, the results of this study reveal that the northern segment of the Shanxi rift is indeed undergoing ENE opening across the whole velocity profile at a slip rate of $1.3 \sim 1.7 \mathrm{~mm} / \mathrm{a}$, which is less than half of the extension rate reported by Shen et al. (20)(0) $)$. We find the Daihai fault is not the only active tectonic structure that is experiencing opening; we also find detectable extension rate across the Kouquan fault, Liulengshan fault, and the north frontal Henshan fault, all of which bound the Datong basin. Although the Daihai basin, which has been recognized as a young rift in geolog- 
ical studies, is more seismically active than the Datong basin, previous studies indeed underestimated the extensional rate across the Datong basin. Thus, the diffuse extensional deformation on the northern Shanxi rift is accommodated by several basin-bounding faults and the Daihai basin together. The moderate earthquakes that have occurred within the Datong basin further support this geodetic finding.

Two end member models have been developed to interpret the diffuse extensive deformation of the northern Shanxi rift. One model proposed a far-field effect of the India-Eurasia convergence; the other involves the westward subduction of the Pacific plate beneath the Asia continent. It is now generally accepted that the above end member plate kinematic models interact spatially and temporally in north China and caused episodic evolution of Cenozoic basins (Zhang et al, 2003). Further geophysical evidences from seismic tomography (Huang and Zhao, 2006; Lei, 2012), geothermal heat flow (He, 2015), and the thickness of lithosphere (Tang et al., 2013) appear to provide the necessary information to address this question. From geodetic view, GPS inferred right-lateral slip rate along the different segments of Shanxi rift and earthquake induced right-lateral offsets verify the counterclockwise rotation of the Ordos block, which is a result of pushing stress from northeastern Tibetan Plateau. On the other hand, GPS observation 
have provided evidence of extensive deformation due to the westward subduction of the Pacific plate. For instance, continuous GPS station in North China recorded far field coseismic deformation of the $2011 \mathrm{Mw} 9.0$ Tohoku-Oki earthquake (Zhao et al., 2012). Static offsets caused by coseismic rupture along subduction area lead to static extensional strain in North China (Wang et al., 2011b). Although the induced strain rate is only approximately $1 \times 10^{-8} / a$ in Shanxi rift system, it sheds light on understanding crustal deformation of North China.

\subsection{Earthquake cycle in the central segment of Shanxi rift}

GPS observed short term slip rates along active faults can deviate from long term geological values due to unmodeled transient process associated with the earthquake cycle (Hilley et al., 20(09). Rheology of lithosphere plays an important role for the earthquake cycle modelling (Devries and Meade, 2013). A complete historic earthquakes occurred along the Shanxi rift have been recorded. One of the strongest events occurred at Hongdong in 1303, which ruptured Huoshan fault in the south and Taigu fault in the north, with a total rupture length of approximately $160 \mathrm{~km}$ and coseismic slip of 6 10 m (Jiang et al., 20(04). Another magnitude of 7.75 earthquake attacked the Lenfen Basin 392 year later. Geodetic data following large earthquakes suggest the viscoelastic relaxation driven by viscous flow in lower crust and upper mantle is almost totally relaxed after more than 100 years. 
The latest study suggest GPS data can detect transient late postseismic deformation following the 1700 M9 Cascadia subduction earthquake(Pollitz et al,, 20(08). We believe our GPS inferred right-lateral slip rates along the Shanxi rift are not biased by transient deformation. Integrating our new results and those from Wang et al. (20)la), the right-lateral slip rate along the central segment is around 1.0 $\mathrm{mm} / \mathrm{a}$. On the basis of this geodetic observed slip rate and average coseismic slip of 1303 Hongdong earthquake, the recurrence interval of this typical event is about 6000 years, which is 3 4 times larger than the estimate by Xu et al. (1993).

Given the low slip rate in North China and long recurring interval of large earthquakes, it is a big challenge to evaluate the seismic hazards along the faults in this region.

\section{Conclusions}

The density and quality of the GPS velocity data, combined with a detailed analysis of the graben-bounding faults that accommodate the current strain accumulation, allow estimation of the contemporary kinematics and slip rates on major faults surrounding the Ordos block. Our results show a weak counterclockwise rotation of the block with respect to the Eurasia plate, confirming that it is stable and rigid like the Sichuan and Tarim basins. Compared to previous results 
we not only confirm the first-oder kinematic pattern but also detect detailed kinematic processes along the graben-bounding faults. For instance, an extensional rate of approximately $1.3 \sim 1.7 \mathrm{~mm} / \mathrm{a}$ along northwest-southeast profiles across both the Daihai and Datong basins is measured, indicating both the Daihai and Datong Basin are accommodating the opening displacement of northern segment of the Shanxi rift. By integrating GPS inferred interseismic kinematic deformation and static strain changes induced by $2011 \mathrm{Mw} 9.0$ Tohoku-Oki earthquake, it is prone to conclude that the both the Indo-Asian collision and Pacific-Asia subduction models contribute to the extensional structures in North China. In addition, modern GPS derived low slip rates along graben-bounding faults and several M8 historic earthquakes occurred in the graben systems indicate the recurrence interval of typical large earthquake is a long time span, increasing the challenge of earthquake hazard assessment in this region. For the case of the Liupanshan thrust fault, there is not significant velocity difference across the fault in the near field, however the far-field shortening rate reaches $3.0 \mathrm{~mm} / \mathrm{a}$. It seems the shallow portion of the fault is locked in interseismic stage. Therefore a detailed fault coupling ratio distribution should be inverted using dense geodetic data especially the vertical motion in future. 


\section{Acknowledgment}

We acknowledge the Crustal Movement Observation Network of China (CMONOC)

for providing GPS data of China, and SOPAC for the global solutions. We greatly thank Roland Bürgmann and two reviewers for valuable comments and suggestions to improve this paper. The authors also thank for Qi Wang and Qiyun Lei for helpful discussion. A software package, Generic Mapping Tool (GMT), was used to plot all the figures. GPS data were processed using the GAMIT/GLOBK software. This research was supported by Foundation of Institute of Seismology, CEA. grant No. IS201326118 and Chinese National Science Foundation grant No. 41304019.

\section{References}

Altamimi, Z., Dam, T.V., Ray, J., 2011. Quality assessment of GPS reprocessed terrestrial reference frame. GPS Solution , 219-231doi:10.1007/ \$10291-010-0184-6.

Blewitt, G., Lavalle, D., 2002. Effect of annual signals on geodetic velocity. Journal of Geophysical Research 107.

Calais, E., Dong, L., Wang, M., Shen, Z., Vergnolle, M., 2006. Continental defor- 
mation in Asia from a combined GPS solution. Geophysical Research Letters 33, 1-6. doi:10.1029/2006GL028433.

Chen, Z., Burchfiel, B.C., Liu, Y., King, R.W., Royden, L.H., Tang, W., Wang, E., Zhao, J., Zhang, X., 2000. Global Positioning System measurements from eastern Tibet and their implications for India / Eurasia. Journal of Geophysical Research 105, 215-227.

Cowgill, E., 2007. Impact of riser reconstructions on estimation of secular variation in rates of strikeslip faulting: Revisiting the Cherchen River site along the Altyn Tagh Fault, NW China. Earth and Planetary Science Letters 254, 239-255. doi:10.1016/j.epsl.2006.09.015.

Davis, G.a., Darby, B.J., 2010. Early Cretaceous overprinting of the Mesozoic Daqing Shan fold-and-thrust belt by the Hohhot metamorphic core complex, Inner Mongolia, China. Geoscience Frontiers 1, 1-20. URL: http:// linkinghub.elsevier.com/retrieve/pii/S1674987110000022, doi:10. $1016 / j . g s f .2010 .08 .001$.

Deng, Q., Liao, Y., 1996. Paleoseismology along the range-front fault of Helan Mountains, north central China. Journal of Geophysical Research 101, 58735893. 
Devries, P.M.R., Meade, B.J., 2013. Earthquake cycle deformation in the Tibetan plateau with a weak mid-crustal layer. Journal of Geophysical Research: Solid Earth 118, 3101-3111. doi:10.1002/jgrb.50209.

Gan, W., Zhang, P., Shen, Z.K., Niu, Z., Wang, M., Wan, Y., Zhou, D., Cheng, J., 2007. Present-day crustal motion within the Tibetan Plateau inferred from GPS measurements. Journal of Geophysical Research 112, 1-14. doi:10.1029/ $2005 J B 004120$.

Hao, M., Wang, Q., Shen, Z., Cui, D., Ji, L., Li, Y., Qin, S., 2014. Tectonophysics Present day crustal vertical movement inferred from precise leveling data in eastern margin of Tibetan Plateau. Tectonophysics 632, 281292. URL: http://dx.doi.org/10.1016/j.tecto.2014.06.016, doi:10. $1016 / j \cdot$ tecto 2014.06 .016 .

He, J., Liu, M., Li, Y., 2003. Is the Shanxi rift of northern China extending? Geophysical Research Letters 30, 2213. URL: http://doi.wiley.com/10. 1029/2003GL018764, doi:10.1029/2003GL018764.

He, L., 2015. Thermal regime of the North China Craton: Implications for craton destruction. Earth-Science Reviews 140, 14-26. URL: http:// 
linkinghub.elsevier.com/retrieve/pii/S0012825214001901, doi:10. 1016/j.earscirev.2014.10.011.

Herring, T., 2003. Matlab tools for viewing gps velocities and time series. GPS Solutions 7, 194-199. doi:10.1007/\$s10291-003-0068-0.

Herring, T.A., King, R.W., McClusky, S.C., 2010. Documentation of the gamit and globk gps software release 10.4. Mass. Inst. of Technol., Cambridge .

Hilley, G.E., Johnson, K.M., Wang, M., Shen, Z.K., Bürgmann, R., 2009. Earthquake-cycle deformation and fault slip rates in northern Tibet. Geology 37, 31-34. URL: http://geology.gsapubs.org/cgi/doi/10.1130/ G2515/A.1, doi:10.1130/G25157A.1.

Huang, J., Zhao, D., 2006. High-resolution mantle tomography of China and surrounding regions. Journal of Geophysical Research 111, B09305. URL: http: //doi.wiley.com/10.1029/2005JB004066, doi:10.1029/2005JB004066.

Jiang, W., Deng, Q., Xu, X., Xie, X., 2004. Surface rupture zone of the 1303 hongtong $\mathrm{m}=8$ earthquake, shanxi province. ACTA Seismologica Sinica 26, $355-362$.

Lei, J., 2012. Upper-mantle tomography and dynamics beneath the North 
China Craton. Journal of Geophysical Research 117, 1-29. doi:10.1029/ 2012JB009212.

Li, Q., You, X., Yang, S., Du, R., 2012. A precise velocity field of tectonic deformation in china as inferred from intensive gps observations. Sci. China Ser. D 42, 629. URL: http://earth.scichina.com:8080/sciD/CN/abstract/ article_b07409.shtm1.

Liu, M., Shen, Z., Wang, S., Wang, M., Wang, Y., 2007. Active tectonics and intracontinental earthquakes in China: The kinematics and geodynamics. The Geological Society of America 2425, 299-318. doi:10.1130/2007.2425(19)

Ma, X.Y., 1987. Lithospheric dynamics map of china and adjacent seas $(1: 4,000,000)$ and explanatory notes. Geological Publishing House, China .

Ma, Z., Chen, X., Ye, S., Nai, X., Wei, Z., Chen, J., Ning, J., Xu, H., Ding, G., 2001. Contemporary crustal movement of continental china obtained by global positioning system (gps) measurements (in chinese). Sci. Bull. 46, 1118-1120.

Meade, B.J., 2007. Algorithms for the calculation of exact displacements, strains , and stresses for triangular dislocation elements in a uniform elastic half space. 
Computers\&Geosciences 33, 1064-1075. doi:10.1016/j.cageo.2006.12. 003.

Meade, B.J., Hager, B.H., 2005. Spatial localization of moment deficits in southern California. Journal of Geophysical Research 110, 1-19. doi:10.1029/ 2004.JB(0)3331.

Min, W., Jiao, D., Chai, C., Zhang, P., Mao, F., 2003. Characteristics of the active Luoshan Fault since Late Pleistocene, North Central China. Annals of Geophysics 46.

Molnar, P., Tapponnier, P., 1975. Cenozoic Tectonics of Asia: Effects of a Continental Collision. Science 189, 419-426. URL: http://www.ncbi.nlm.nih. gov/pubmed/17781869, doi:10.1126/science.189.4201.419.

Niu, Z., Wang, M., Sun, H., You, X., Gan, W., Xue, G., Hao, J., Xin, S., Wang, Y., Wang, Q., Wang, Y.X., Li, B., 2005. Contemporary velocity field of crustal movement of chinese mainland from global positioning system measurements. Chin. Sci. Bull. 50, 939-941.

Northrup, C.J., Royden, L.H., Burchfiel, B.C., 1995. Motion of the Pacific plate relative to Eurasia and its potential relation to Cenozoic extension along the 
eastern margin of Eurasia. Geology 23. doi:10.1130/0091-7613(1995) 023<0719:MUTPPR>2.3.CU;2.

Pollitz, F.F., McCrory, P., Svarc, J., Murray, J., 2008. Dislocation models of interseismic deformation in the western United States. Journal of Geophysical Research 113, B04413. URL: http://doi.wiley.com/10.1029/ 200/JB005174, doi:10.1029/2007JB005174.

Reilinger, R., McClusky, S., Vernant, P., 2006. GPS constraints on continental deformation in the AfricaArabiaEurasia continental collision zone and implications for the dynamics of plate interaction. Journal Geophysical Research 111. doi:doi:10.1029/2005JB004051.

Replumaz, A., 2003. Reconstruction of the deformed collision zone Between India and Asia by backward motion of lithospheric blocks. Journal of Geophysical Research 108. doi:10.1029/2001JB000661.

Shen, Z.K., Lu, J., Wang, M., Bürgmann, R., 2005. Contemporary crustal deformation around the southeast borderland of the Tibetan Plateau. Journal of Geophysical Research 110. doi:10.1029/2004JB003421.

Shen, Z.K., Wang, M., Li, Y., Jackson, D.D., Yin, A., Dong, D., Fang, P., 2001. 
Crustal deformation along the Altyn Tagh fault system, western China, from GPS. Journal of Geophysical Research 106, 30607-30621.

Shen, Z.K., Zhao, C., Yin, A., Li, Y., Jackson, D.D., Fang, P., Dong, D., 2000. Contemporary crustal deformation in east Asia constrained by Global Positioning System measurements. Journal of Geophysical Research 105, 5721-5734.

Tang, Y., Chen, Y.J., Zhou, S., Ning, J., Ding, Z., 2013. Lithosphere structure and thickness beneath the north china craton from joint inversion of ambient noise and surface wave tomography. Journal of Geophysical Research: Solid Earth $118,2333-2346$.

Tapponnier, P., Molnar, P., 1977. Active faulting and tectonics in China. Journal of Geophysical Research 82, 2905-2930.

Thatcher, W., 2007. Microplate model for the present-day deformation of Tibet. Journal of Geophysical Research 112, B01401. URL: http://doi.wiley. com/10.1029/2005JB004244, doi:10.1029/2005JB004244.

Tian, Z., Han, P., Xu, K., 1992. The Mesozoic-Cenozoic East China rift system. Tectonophysics 208, 341-363. doi:10.1016/0040-1951(92)90354-9.

Walpersdorf, A., Manighett, I., Mousavi, Z., Tavakoli, F., Vergnolle, M., Jadidi, 
A., Hatzfeld, D., Aghamohammadi, A., Bigot, A., Djamour, Y., Nankali, H., Sedighi, M., 2014. Present-day kinematics and fault slip rates in eastern Iran, derived from 11 years of GPS data. Journal of Geophysical Research 119, 1359-1383. doi:10.1002/2013JB010620. Received.

Wang, H., Liu, M., Cao, J., Shen, X., Zhang, G., 2011a. Slip rates and seismic moment deficits on major active faults in mainland China. Journal of Geophysical Research 116. doi:10.1029/2010JB007821.

Wang, M., Li, Q., Wang, F., Zhang, R., 2011b. Far-field coseismic displacements associated with the 2011 Tohoku-oki earthquake in Japan observed by Global Positioning System. Chinese Sci Bull 56, 1593-1596.

Wang, M., Shen, Z.K., Niu, Z., Zhang, Z., Sun, H., 2003. Contemporary crustal Deformation and active blocks model of China mainland (in Chinese). Sci. China, Ser: D 33(suppl.), 21-32.

Wang, Q., Zhang, P.Z., Freymueller, J.T., Bilham, R., Larson, K.M., Lai, X., You, X., Niu, Z., Wu, J., Li, Y., Liu, J., Yang, Z., Chen, Q., 2001. Present-day crustal deformation in China constrained by global positioning system measurements. Science 294, 574-577. URL: http://www.ncbi.nlm.nih.gov/ pubmed/11641493, doi:10.1126/science.1063647. 
Wang, W., Yang, S., Wang, Q., 2009. Crustal block rotations in Chinese mainland revealed by GPS measurements. Earthquake Science 22, 639649. URL: http://link.springer.com/10.1007/s11589-009-0639-4, doi:10.1007/s11589-009-0639-4.

Xu, X., MA, X., DENG, Q., 1993. Neotectonic activity along the Shanxi rift system, China. Tectonophysics 219, 305-325. doi:10.1016/0040-1951(93) 90180-R.

Yin, A., 2010. Cenozoic tectonic evolution of Asia: A preliminary synthesis. Tectonophysics 488, 293-325. URL: http:// linkinghub.elsevier.com/retrieve/pii/S0040195109003217, doi:10. $1016 / j$. tecto.2009.06.002.

Zhang, P.Z., Shen, Z., Wang, M., Gan, W., Bürgmann, R., Molnar, P., Wang, Q., Niu, Z., Sun, J., Wu, J., Hanrong, S., Xinzhao, Y., 2004. Continuous deformation of the Tibetan Plateau from global positioning system data. Geology 32, 810-812. URL: http://geology.gsapubs.org/cgi/doi/10. 1130/G20554.1, doi:10.1130/G20554.1.

Zhang, Y., Ma, Y., Yang, N., Shi, W., Dong, S., 2003. Cenozoic extensional stress 
evolution in North China. Journal of Geodynamics 36, 591-613. doi:10.1016/ j.jog.2003.08.001.

Zhang, Y.Q., Mercier, J.L., Vergly, P., 1998. Extension in the graben systems around the Ordos (China), and its contribution to the extrusion tectonics of south China with respect to Gobi-Mongolia. Tectonophysics 285, 41-75. doi:10.1016/S0040-1951(97)00170-4.

Zhao, B., Huang, Y., Zhang, C., Wang, W., Tan, K., Du, R., 2015. Crustal deformation on the chinese mainland during 1998-2014 based on gps data. Geodesy and Geodynamics doi:10.1016/j.geog.2014.12.006.

Zhao, B., Wang, W., Yang, S., Peng, M., Qiao, X., Du, R., Nie, Z., 2012. Far field deformation analysis after the Mw9.0 Tohoku earthquake constrained by cGPS data. Journal of Seismology 16, 305-313. URL: http://link.springer. com/10.1007/s10950-011-9271-6, doi:10.1007/s10950-011-9271-6. 
Fig. W: Topographic relief and tectonic map of the Ordos block and its surrounding area. Pink solid circles are earthquakes from 780 B.C. to 2015. The earthquake focal mechanisms were obtained the Harvard CMT catalog, 19762015. Active faults were adapted from Zhang et al. (2003). Red solid circles denote cities in the rift systems. Abbreviations are HLF, Helanshan fault; HHF, Huanghe fault; BYF, Bayanwula shan fault; LSF, Langshan fault; SETF, Seerteng shan fault; NFOF, north frontal Ordos fault; DQF, Daqingshan fault; DHF, Daihai fault; KQF, Kouquan fault; LLF, Liulengshan fault; NHSF, north frontal Hengshan fault; WTSF, Wutaishan fault; XZSF, Xizhoushan fault; JCF, Jiaocheng fault; TGF, Taigu fault; HSF, Huoshan fault.

Fig. [2]: The GPS horizontal velocity field around the Ordos block with respect to the stable Eurasian reference frame. The error ellipses represent $95 \%$ confidence.

Fig. B: Horizontal GPS velocity data used for Euler vector estimation. (a) Observed and modelled GPS velocities in Eurasia reference frame, (b) residual velocities between observed and predicted using block rotation model. Inset shows histogram of residuals, which are fit well by a Gaussian distribution with mean of 0.18 and standard deviation of $0.68 \mathrm{~mm} / \mathrm{a}$.

Fig. 国: GPS horizontal velocity field with respective to the stable Ordos block. 
The black rectangular frames surrounding fault segments mark the regions within which GPS stations are depicted for slip rate estimation; velocity profiles for these stations are illustrated in Figure [1. Blue and red labels in the gray boxes are extensional(positive in sinistral ) and strike slip(positive in extension) rates respectively. Fig. [5: GPS velocity profiles across major active faults (rifts) around the Ordos block. (left) Fault-parallel (sinistral positive) and (right) fault-normal (extensional positive) components, with respect to the distance along the profile. Data entries are indexed by regions outlined in Figure 4 . Vertical bars denote the locations of main faults. Gray bars depict the scattering range of data on both sides of the fault.

Fig. 6: (continuation of Figure [5) GPS velocity profiles across major active faults (rifts) around the Ordos block. (left) Fault-parallel (sinistral positive) and (right) fault-normal (extensional positive) components, with respect to the distance along the profile. Data entries are indexed by regions outlined in Figure $\mathbb{G}$. Vertical bars denote the locations of main faults. Fault abbreviations as for Figure П. Gray bars depict the scattering range of data on both sides of the fault. Table प: Slip rates of graben-bounding faults around the Ordos block 


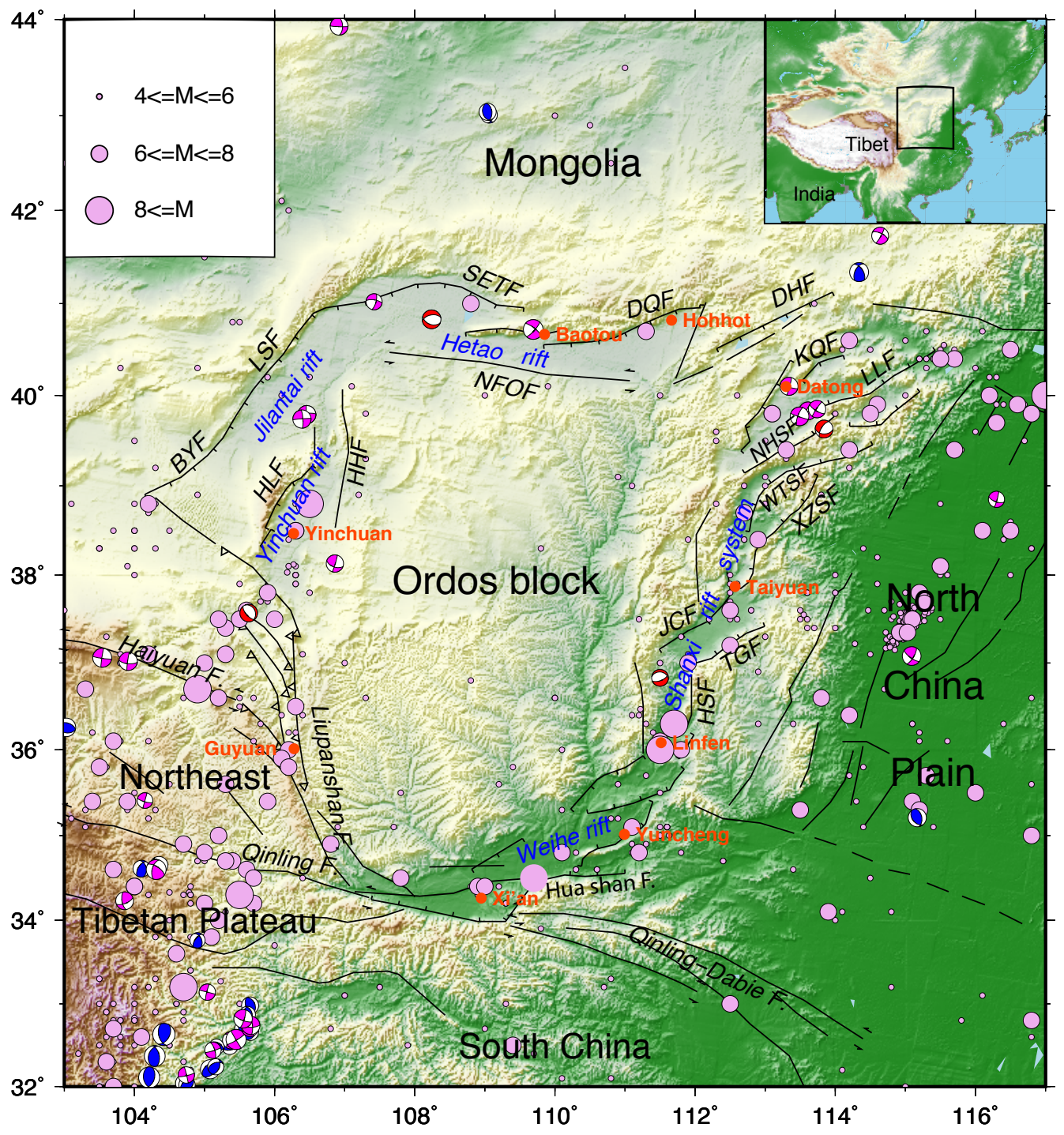

Figure 1: 


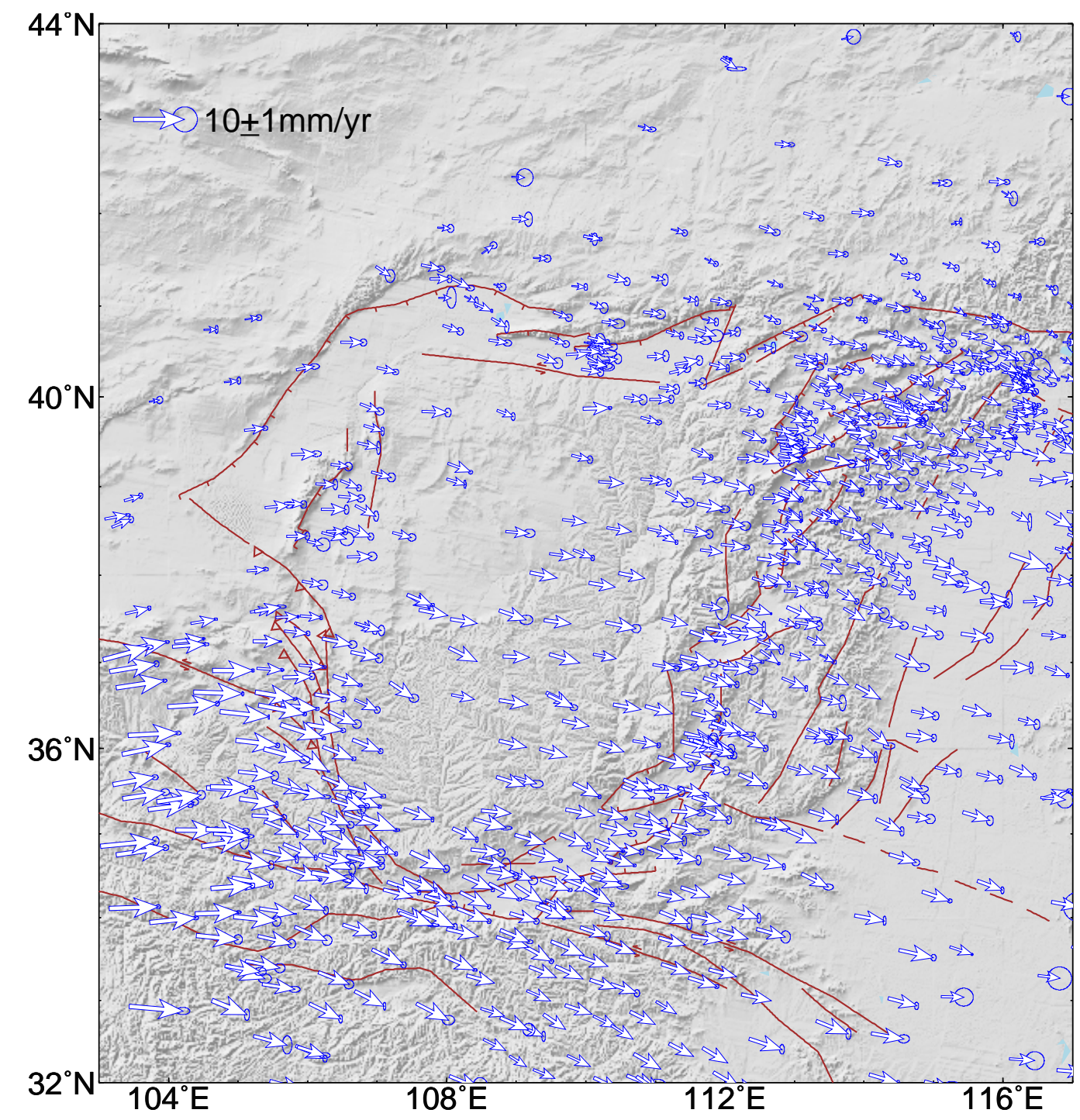

Figure 2: 

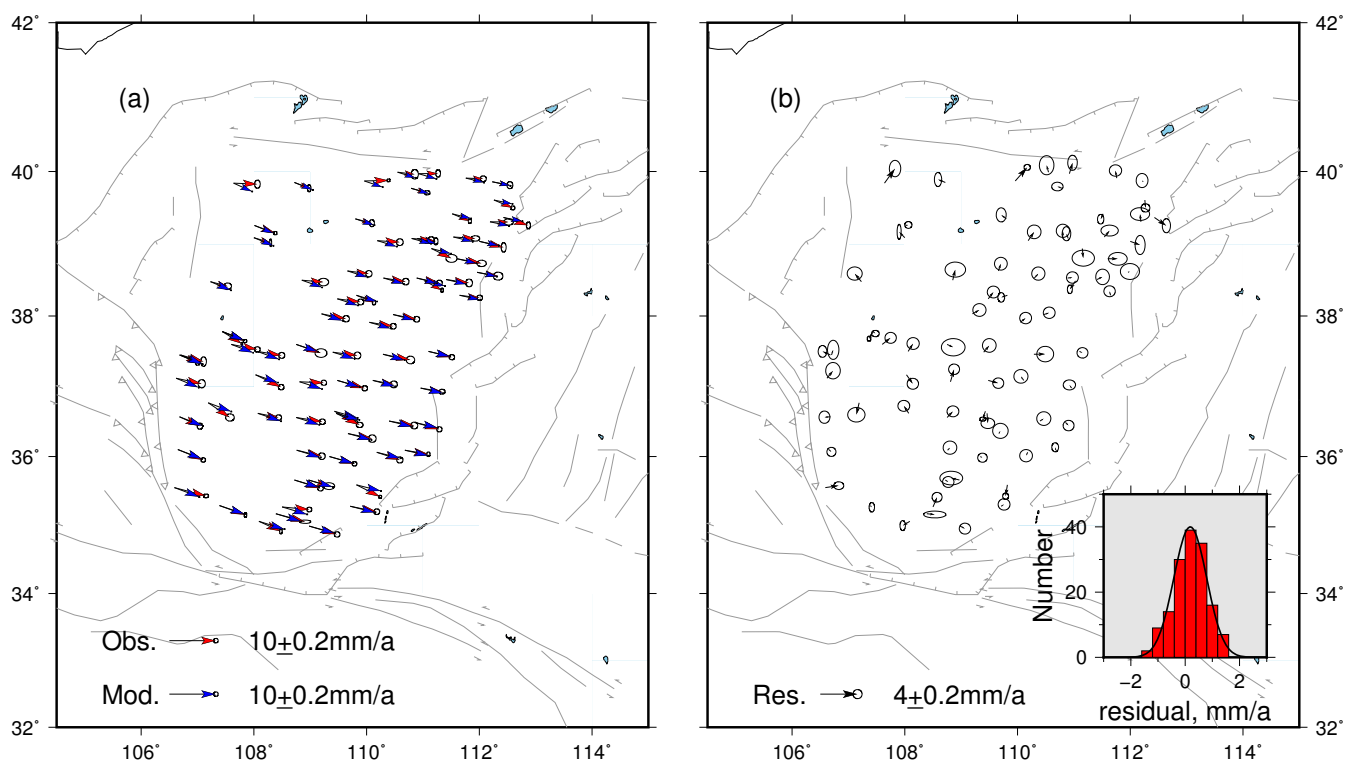

Figure 3: 


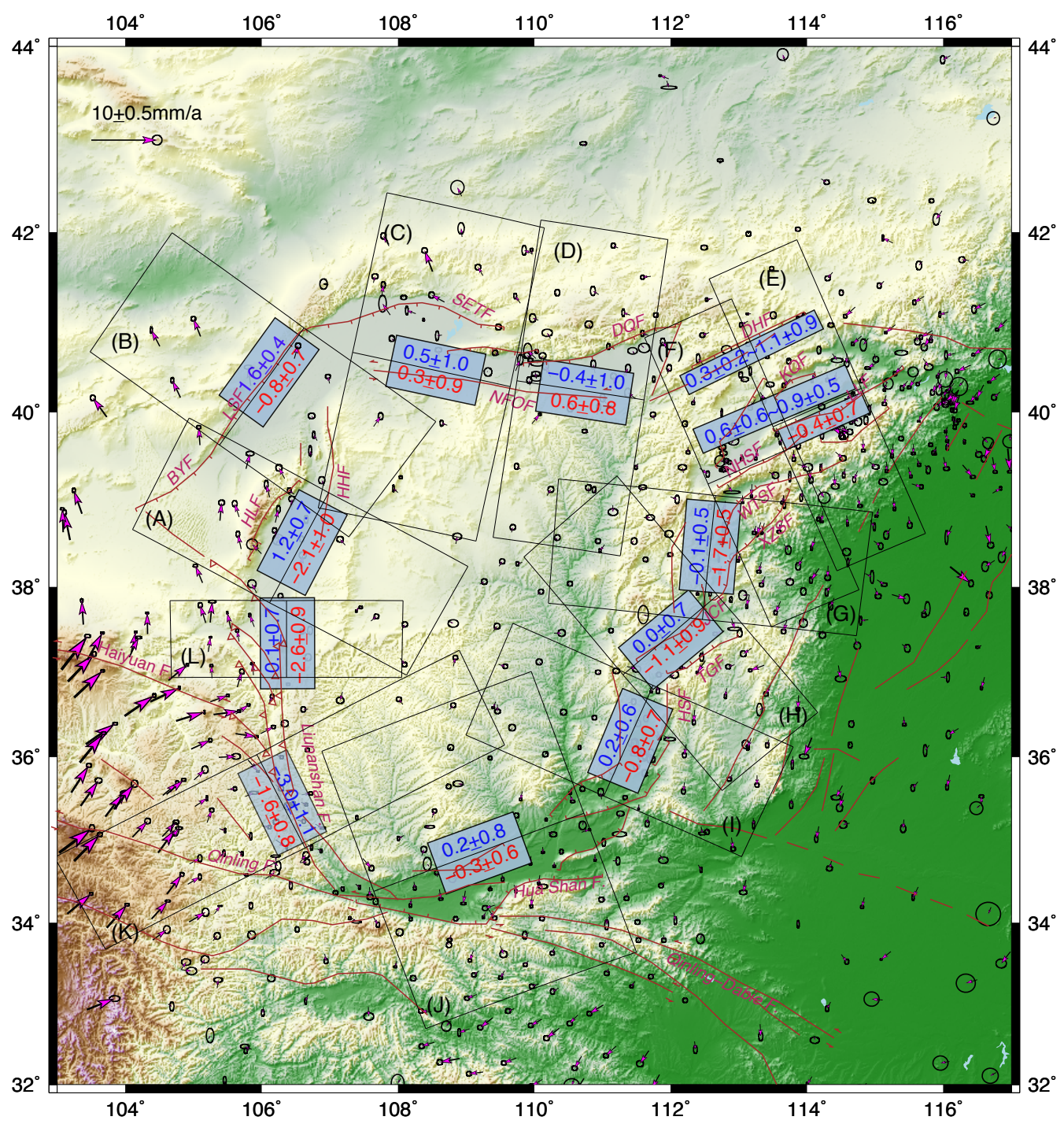

Figure 4: 

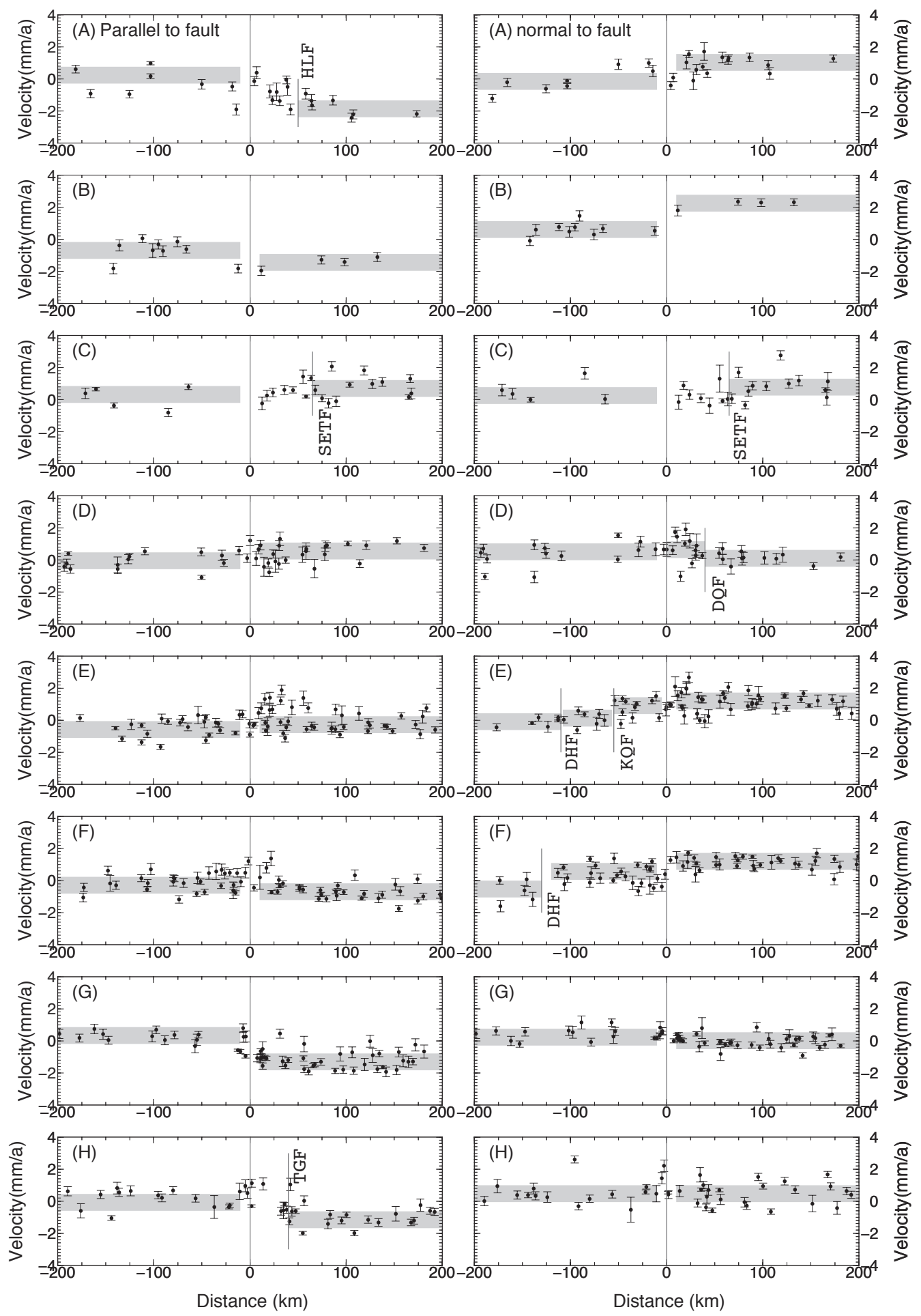

Figtte 5: 

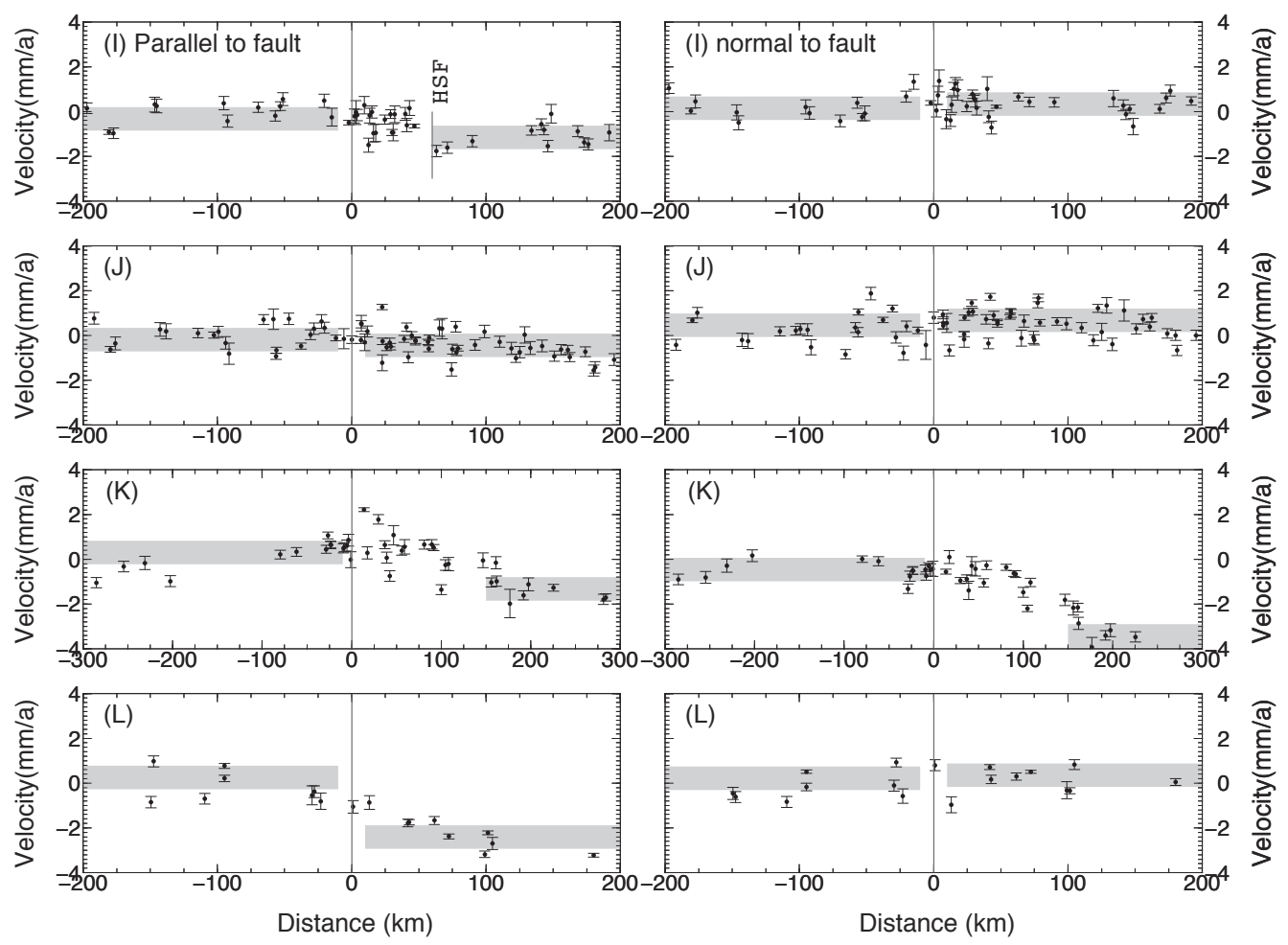

Figure 6: 
Table 1:

\begin{tabular}{lllll}
\hline Profile index & Rift system & Basin/Fault & strike-slip $(\mathrm{mm} / \mathrm{a})^{1}$ & extensional-slip(mm/a $)^{2}$ \\
\hline A & Yinchuan & Yinchuan & $-2.1 \pm 1.0$ & $1.2 \pm 0.7$ \\
B & & Jilantai & $-0.8 \pm 0.7$ & $1.6 \pm 0.4$ \\
C & Hetao & Hetao & $0.3 \pm 0.9$ & $0.5 \pm 1.0$ \\
D & & Baotou-Hohhot & $0.6 \pm 0.8$ & $-0.4 \pm 1.0$ \\
E F & Shanxi & Datong & $-0.4 \pm 0.7$ & $0.6 \pm 0.6 \sim 0.9 \pm 0.5$ \\
E F & & Daihai & - & $0.3 \pm 0.2 \sim 1.1 \pm 0.9$ \\
G & & Xinding & $-1.7 \pm 0.5$ & $-0.1 \pm 0.5$ \\
H & & Taiyuan & $-1.1 \pm 0.9$ & $0.0 \pm 0.7$ \\
I & & Linfen & $-0.8 \pm 0.7$ & $0.2 \pm 0.6$ \\
J & Weihe & Weihe & $-0.3 \pm 0.6$ & $0.2 \pm 0.8$ \\
K & - & Liupanshan & $-1.6 \pm 0.8$ & $-3.0 \pm 1.1$ \\
L & - & Luoshan & $-2.6 \pm 0.9$ & $0.1 \pm 0.7$ \\
\hline
\end{tabular}

${ }^{1}$ Positive denotes sinistral motion; negative dextral motion.

${ }^{2}$ Positive denotes extension (normal fault); negative contraction (reverse fault). 